\title{
Kraepelin in Ceylon
}

\author{
A de Alwis
}

\section{Abstract}

It is a little-known fact that Emil Kraepelin visited Sri Lanka (then Ceylon) in 1904. He travelled around the country from 10 January 1904 to 7 February 1904, visiting various places. Kraepelin's letters to his wife, while providing an itinerary of his travels and activities, give a glimpse of his thinking about the people of Ceylon. Although this trip did not influence his scientific thinking, it clearly offered the psychiatrist opportunities to satisfy his wanderlust and to get better acquainted with Buddhism.

Key words: Emil Kraepelin, Ceylon, Java, Buddhism

SL J Psychiatry 2020; 11(1): 63-70

\section{Introduction}

Emil Kraepelin (1856-1926) is recognised as the founder of modern psychiatry. This is mostly due to his pioneering work on psychiatric nosology and the delineation of schizophrenia (dementia praecox) and bipolar affective disorder (manic depressive insanity). He made significant contributions to many other areas of science including experimental psychology, psychopharmacology, psychiatric genetics, sleep research and criminology (1-5). Despite his great scientific achievements, Emil Kraepelin is a polarising figure today, due to his social and political views on racial hygiene and eugenics (6-8). Another important but unexplored part of Kraepelin's personality was his interest in travel and exploration.

In 1904, Emil Kraepelin visited Sri Lanka (then Ceylon) and spent nearly four weeks travelling around the island (which included a three-day visit to South India). The visit to Ceylon was a stopover in his voyage to the Dutch East Indies to engage in research at the Buitenzorg Asylum in Java (Indonesia). His scientific work at Buitenzorg and the resulting publications are considered to have heralded the birth of transcultural psychiatry $(9,10)$. The time Emil Kraepelin spent in Ceylon did not contribute to the observations he made about the psychopathology and incidence of mental illness in a different culture. However, his experience and recollections, found in his letters, reveal facets of Kraepelin's personality and thinking that are important in forming a better understanding of him. Instead of a tough-minded, brain-focused, hard-nosed nosologist, as he is often remembered his letters reveal a sensitive, empathetic, astute observer with a child-like fascination with the serendipity of travel (1).

The observations he made about people, customs and places in Ceylon have not been published in English before. The information in this article comes from several sources: letters Emil Kraepelin wrote to his family and colleagues before and during his voyage, made accessible through an excellent dissertation by Christoph Bendick in 1989 and published by the Institute for the History of Medicine, Cologne University (10); Kraepelin's memoir (published in 1987) (11); the collected work of Emil Kraepelin by Wolfgang Burgmair et al. (12); and the letters Kraepelin wrote from Ceylon to his wife, Ina. Typed versions of these letters were provided to the author by Christoph Bendick (C. Bendick, personal communication, May 11, 2019) with permission from the Kraepelin family (C. Schmidt-Kraepelin, personal communication, May 1, 2019). These are part of a typewritten copy produced by the late Mrs. Lore Perkow (Ahrensburg) from nine original letters Emil Kreapelin wrote to his wife, Ina. Kraepelin intended these letters to become a travel (letter) diary ("Brieftagebuch") of his expedition (10).

\section{Emil Kraepelin in 1903-04}

At the time of undertaking the research trip to Java (in late 1903), Kraepelin was a distinguished professor of psychiatry in Germany. He had already published (in 1899) a detailed account of his nosological system for psychiatry and the delineation of dementia praecox from manic depression in the sixth edition of his Psychiatrie: Ein Lehrbuch für Studirende und Ärzte (Psychiatry: A 
Text Book for Students and Doctors). At the turn of the century, his writings were attracting a lot of attention not only in Europe but also in England and the US (13-17). His books were translated into English and introduced across the Atlantic. In April 1904, Thomas Johnson wrote in the preface to the first English translation of Kraepelin's work, Lectures on clinical psychiatry, that Kraepelin was the "most original and successful teacher of clinical psychiatry” (18).

\section{Kraepelin the traveller}

It is clear from his memoir that Kraepelin loved to travel. In the five years leading up to his excursion to Java, he spent several weeks every year travelling abroad (11). In fact, his memoir is, in large part, a collection of writings on his travels to far-flung destinations and the people he met, with comparatively less information on his work on clinical psychiatry. Kraepelin often combined his travel with professional training, seeing patients, and his own research projects. He made it a habit to contact colleagues and other scientists in the countries he visited (19). This was no different in his travels to Ceylon and Java. Kraepelin's wanderlust is well demonstrated in a letter to his elder brother, Karl Kraepelin, on 27 January 1905 , in which he wrote "at the moment, my main aim is to earn enough money to travel wherever I want, without any problem" and that "money spent travelling is money spent well" (20).

\section{Two brothers}

Emil Kraepelin embarked on his trip to Java with his brother Karl on 23 December 1903 (Figure 1). Karl Matthias Friedrich Magnus Kraepelin (1848-1915) was an eminent naturalist and taxonomist who specialised in arachnids. At the time of the trip, Karl Kraepelin had already published his seminal monograph about scorpions, Scorpiones und Pedipalpi (in 1899). This was the first complete survey of the world's scorpion fauna. He was also the director of the Natural History Museum in Hamburg.

Correspondence between the two brothers, as well as his memoir, indicate that Emil had a close relationship with Karl and that he greatly admired his brother. Emil was encouraged and influenced by Karl to study natural sciences from an early age (11). It has even been suggested that Emil's greatest contribution to modern psychiatry, his classification of mental illness, may have been influenced by $\operatorname{Karl}(20,21)$.

Karl often travelled with Emil on his trips abroad. In their voyages, the route was often decided by Karl to allow for his own research into the flora and fauna of the places they visited $(11,20)$. During the trip to Java, the comparatively longer period in Ceylon and the places and people they visited appear to have been determined by the interests of Karl rather than those of Emil. The only two individuals that the brothers visited professionally as well as socially (in Ceylon) were the director of the Colombo Natural History Museum, Dr Arthur Willey, and the director of the Royal Botanic Gardens of Peradeniya, Dr JC Willis, most likely organised through the professional contacts of Karl.

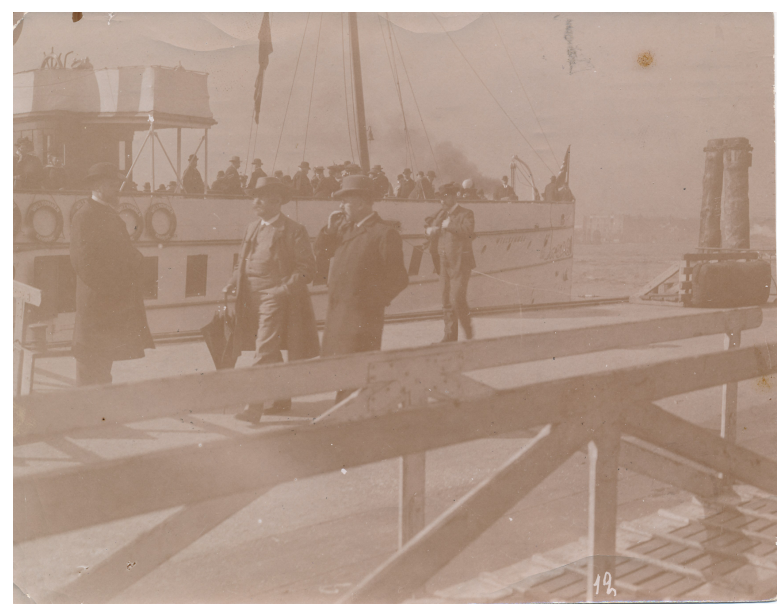

Figure 1. "Before the trip to Lisbon" - Emil and Karl Kraepelin at the Port of Hamburge - Historical Archives of Max-Planck Institute for Psychiatry MPIP - K 16/E.

\section{Travelling in Ceylon - 10 January to 28 January 1904}

The following account of the travels of Emil Kraepelin in Ceylon is informed by the letters Emil wrote to his wife, Ina, on 10 January and 24 January.

\section{Arrival and first impressions}

The steamer 'Gera', carrying the Kraepelin brothers, docked in Colombo Harbour around 4.30am on 10 January 1904. The Kraepelins were met by Dr Arthur Willey, who had come on a boat to pick them up from the ship. The first task was to report to the German consulate. As it was Sunday and the consulate was closed, the brothers were taken to the residence of the German Consul, Philip Freudenberg, in Mount Lavinia, and then driven to the Galle Face Hotel.

On his way to and from the Freudenberg residence, Emil Kraepelin observed the city of Colombo and its inhabitants for the first time. He shared his impressions with his wife, writing:

...The whole way there, led through gardens, past small lakes, through an extremely colourful, picturesque population, so that one wished to have 1000 eyes to capture all these strange images. ...brown to black figures in the bright sunlight, wrapped in colourful garments, the men with an almost circular [illegible] on their heads, which is carried like a diadem, and long flowing tangled black hair, others with turbans or high 
caps, white-bearded prophet-like figures with sparkling young eyes, young men with soft, melancholic traits and dark almond eyes, ...completely naked children, that race with the car, throwing flowers at us, fanatical heads full of majesty and dignity, others with traits of John the Baptist, ...I would have liked to take hundreds of pictures...

The next morning, Monday 11 January 1904, after a sumptuous breakfast at the Galle Face Hotel, Emil and Karl went for a long walk in Colombo City. Emil wrote admiringly of the staff at the Galle Face Hotel and made further observations of the Ceylonese.

...These delicately built people in snow-white suits, barefoot, with a diadem-like comb on their dark hair looped into a knot, with their little black moustaches in their brown faces and their big dark almond eyes, have the ability to guess every wish in advance, are very serious about it, don't need a shout, no invitation, and (they) work without any noise. As soon as one thinks of any desire, it is noticed and satisfied. ...they are present everywhere in large numbers, but are undemanding, always ready to serve, thinking of everything. To the stranger, they appear like big children with their big, rapturous eyes, their grace, their cheerful naturalness and love-worthiness. Even if they torture the stranger with their pushiness, they always remain within the limits of modesty, never become rude and impudent, do not resent when they are ignored. These wonderful slender, graceful bodies! I must confess that these days I have often been overcome with the feeling of shame on us civilized people. Certainly, this is only justified to a limited extent, but so much is certain is that I have never met a people that would have made such a favourable impression both physically and especially in character. Of course, they are not a master race, not a people of the will, but a people who live in harmless kindness and apparently possesses peculiar attachments of the mind. Nowhere do we see squabbling, dissatisfaction, strife, but everywhere peaceful, harmonious coexistence. Very striking is the strong romantic trait, which is expressed on numerous faces. Among the younger ones (there) are ...stunning models of St. John or Christ figures, among the older ones distinct prophets in all possible forms.

\section{Dr J.B. Spence and psychiatry in Ceylon at the turn of the century}

Emil and Karl Kraepelin were hosted by Dr Willey and his wife for dinner on the evening of 11 January. At this dinner Emil Kraepelin met the British medical superintendent of the Cinnamon Gardens Asylum, Dr John Buchan Spence.
Emil Kraeplin's impression of the medical superintendent was not wholly favourable. He wrote that Dr Spence had "no idea about psychiatry", was unaware of who he was and was "most uncomfortable" having to meet him. Given Emil Kraepelin's standing in the psychiatry world at that time, it is surprising that Dr Spence did not know of him. Before the trip, Emil Kraepelin had been forewarned by the superintendent of the Buitenzorg Asylum, Dr JW Hoffmann, that visiting mental institutions in the British colonies of Ceylon, India and Singapore would be completely unproductive. Dr Hoffman believed that psychiatric care in the British colonies was a century behind the care in the Dutch East Indies (10). This negative impression created in Kraepelin's mind appears to have strengthened after the meeting with Dr Spence. At the turn of the century, Ceylon's British-governed mental health services were under considerable pressure caused by Britain's financial constraints after the Boer War (1899-1902). At the end of 1903, the main asylum in Ceylon, Cinnamon Gardens (which had been open for only 15 years), was severely overcrowded, understaffed and lacked basic funding to run proper therapeutic programs. Dr Spence had one medical officer and several attendants to care for more than 500 inmates in an institution that was designed for half that number (22). Despite Emil Kraepelin's poor opinion, Dr Spence's administrative reports give the impression of a knowledgeable and practical medical administrator who was struggling with the colonial government to address urgent issues within the asylum.

\section{Kraepelin in Kandy}

Early in the morning on 13 January, the Kraepelin brothers boarded a train in Colombo and arrived in Kandy around midday. Emil described in some detail the landscape during the trip, the service at the Queen's Hotel (which was their base for exploration of the central part of the country), and his impressions of the city of Kandy. He noted to his wife that Kandy reminded him of Baden Baden, a place in Germany they regularly enjoyed.

The following day, the brothers travelled by train to see the Botanical Gardens at Peradeniya. They were amazed by the variety of plant species in the gardens. Emil noted that he took many photographs so that his wife could understand the "opulence" of the gardens, at least to an extent. At the gardens, Karl collected insects for his zoological studies, while Emil enjoyed strolling around the garden taking pictures. Later in the afternoon, they visited a tea estate, where they were much inconvenienced by rain and leeches. Emil wrote about the leeches:

...we got to know for the first time the plague of the leeches, which came marching in regiments, as soon as one set foot on the damp lawn, ...in incalculable quantities ...only one bit Karl, with me none at all, but we got respect for them. 
On 15 January, Emil Kraepelin observed the Poya day ceremonies in Kandy. He described the event:

The shores of the lake, the facade of the temple and the neighbouring buildings were illuminated with thousands and thousands of small coconut oil lamps, ...Priests stood on top of the verandas of the temple ...In the crowd we noticed some magnificent figures in strange costumes, ...The warm summer evening air, the dark lake, the high trees, the muffled sound of drums and cymbals from the temple surrounded by the crowd - it was like a fairy tale from 1001 nights.

Emil Kraepelin was impressed by the peaceful behaviour of the Ceylonese masses gathered to see the celebrations. He described them as "quiet and decent" and hypothesised that this was due to the "complete absence of alcohol" in Ceylonese society. Despite Kraepelin's observation, at the time of his visit alcohol was a significant social problem in Ceylon. As a result of legal and economic changes implemented by the British colonial government on alcohol production and distribution, alcohol consumption had risen dramatically since the middle of the $19^{\text {th }}$ century $(23,24)$. In fact, the colonial government made more than three million rupees in revenue from alcohol tariffs in 1903 alone (close to threequarters of the total expenditure of the Public Works Department the same year) (25). Around the same time, the temperance movement in Ceylon was trying hard to limit the number of taverns being opened around the island $(23,24)$. Kraepelin was a lifelong fervent enemy of alcohol and completely abstinent himself (11).

\section{Travelling to Anuradhapura}

On the morning of 16 January, the Kraepelin brothers took a train from Kandy to Matale and from Matale, a motor car to Dambulla. At Dambulla, they stayed at the Government Rest House, where Emil was pleasantly surprised to find a particular type of armchair (Hansi Putuva-lounging chair) he had not encountered before. He described this unique piece of furniture to his wife:

...easy chairs, i.e., very comfortable chairs with tremendously long backrests which are intended for hanging up the legs. In these chairs one rests excellently.

Before travelling to Anuradhapura, the brothers visited the rock caves in Dambulla, staying the night in Tirapane Rest House.

\section{Kraepelin in Anuradhapura}

After a two-night journey, Emil and Karl Kraepelin arrived in Anuradhapura on 19 January. On the same day they travelled to the Shri Maha Bodhiya, a sacred fig tree in Anuradhapura. In a letter to his wife dated 25 January, he wrote that he was "particularly interested" in his visit to the holy Bodhi tree. In the same letter, Emil gave the history, religious significance and a fair description of the holy tree's appearance. He collected leaves from the Shri Maha Bodhiya to send to colleagues in Germany (Figure 2), gave money to Buddhist priests and took multiple photographs of monkeys (playing among the branches of the sacred tree), child monks and some Burmese priests.
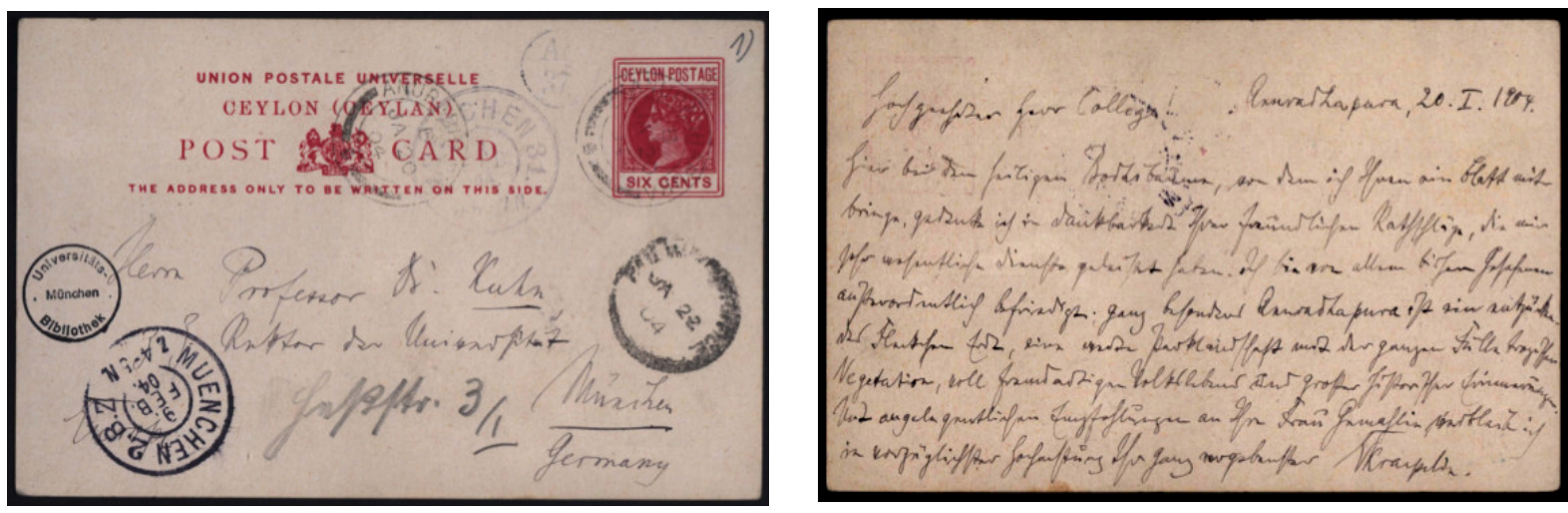

Figure 2. Postcard sent by Emil Kraepelin to Ernst Kuhn on the 20 January 1904 (University Library of Munich, Estate of Ernst Kuhn)

Translation of content:

Dear Colleague!

Here at the sacred Bodhi tree, from which I bring you a leaf. I remember with gratitude your kindly advice, which has rendered me very essential services. I am extremely satisfied with everything I have seen so far; especially Anuradhapura is a delightful patch of earth, a vast parkland with all the richness of tropical vegetation, full of alien folk life and great historical memories.

With proper recommendations to your wife, I remain in the utmost respect your most devoted

E Kraepelin. 
In Anuradhapura, the brothers also visited the Thuparama Dagoba, the Tissa Wewa tank, and finally a small temple built into some rock cliffs rising from the plain. The only photo of the many taken during the whole trip that the author has been able to locate is one of Emil Kraepelin, wearing his khaki safari suit and pith helmet and standing in front of the Thuparama Dagoba (Figure 3).

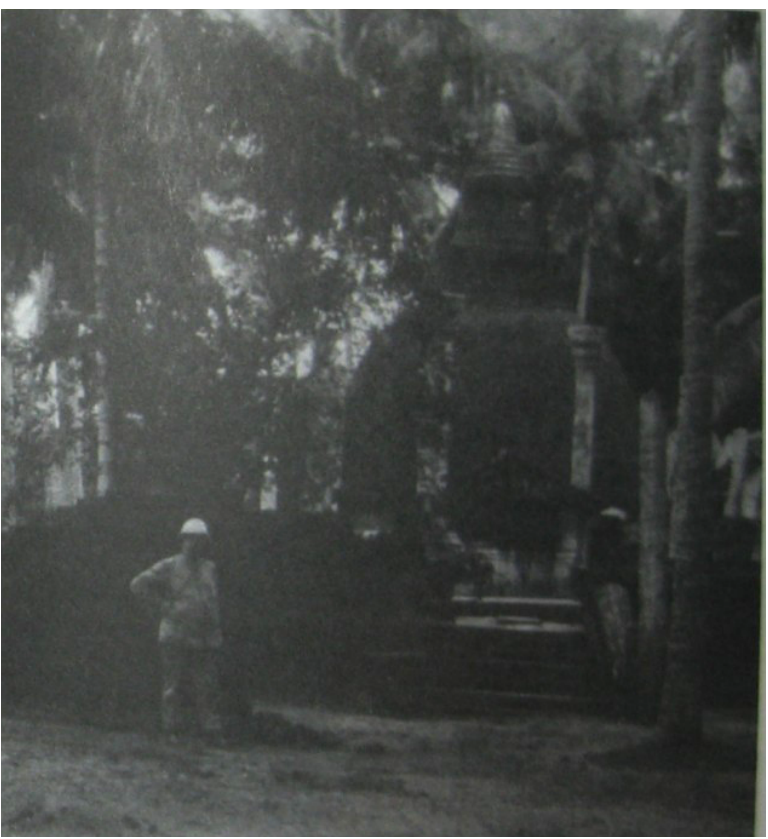

Figure 3. Emil Kraepelin standing in front of the Thuparama Dagoba, Anuradhapura, Ceylon, 1904 (Kraepelin in München I (1903-1914) (21 pp. 161), published with permission from the Historical Archives of Max-Planck Institute for Psychiatry.

\section{Visiting Mihintale and Sigiriya}

On 20 January the brothers travelled by ox cart to Mihintale to see the tomb of Mihindu Thera (who is considered to have introduced Buddhism to Ceylon). They climbed the thousand plus steps to the summit. On the way up, Emil saw the Ambasthala Dagoba as well as the Mihindu Guha (Mahinda's Bed). He described these sites in some detail to his wife, including a surprisingly accurate account of the history and the legend behind it.

Emil's letters of 24 and 25 January are peppered with descriptions of various things that he observed and found interesting on his way to Mihintale and Sigiriya. These included the toilet and bathing habits of the locals, a little settlement of huts and their inhabitants (Emil identified them as belonging to the Rhodiya cast) and implements used by the locals as umbrellas.

On 22 January Emil and Karl visited the ancient rock fortress of Sigiriya. The journey to Sigiriya was on an ox cart in the pouring rain. Emil Kraepelin described this leg of the journey as being the most arduous. At Sigiriya, the rain was too heavy to allow the brothers to climb the rock. Despite this, Emil decided to take it on, managing to climb to the galleries level. However, from the galleries the climb was too dangerous and he did not go further. Again, Emil Kraepelin described the story of the power struggle between King Datusena, Kashyapa and Mugalan and the need for the Sigiriya fortress in excellent detail in his letters. The journey back from Sigiriya was equally difficult; the roads were muddy, the oxen were tiring and the brothers had to get off the cart and walk along the muddy roads in the rain. The brothers made it back to Dambulla Rest House around dinner time. The next day they left for Kandy, reaching Queen's Hotel by $5 \mathrm{pm}$.

\section{Nuwara Eliya and climbing Piduruthalagala}

On 24 January 1904, the Kraepelins travelled by train to Nuwara Eliya. The following day, they left their hotel at 6.15am to climb Piduruthalagala (the highest mountain in Ceylon). It took them two-and-a-half hours to reach the summit. Once there, they had a picnic and then started the descent. On the way down they picked plant specimens for Karl's collection.

In Nuwara Eliya, incessant rain continued for several days, forcing the brothers to spend time indoors in front of a fire. Emil used this time to write to his wife. He started his letter dated 25 January 1904 by giving a vivid description of the people, flora and fauna of the island. His description of the Ceylonese he had come across reflected his fascination as well as his biases about what he and his peers considered a "primitive culture". He described facial features, clothing, colours and actions of men, women and children, in a valiant attempt to give his wife a picture for her own imagination:

... it's like being at the theatre; one colourful picture after another passes me by, and I want to capture them all, in order to be able to show them to you. But how little am I able to give you an idea of this strange world! Such an abundance of details cannot be portrayed, whose common feature is the picturesque. Truly, if I were a painter, I would not tire of drawing over and over again these people, each of whom is a model, and of reproducing this colourful, exuberant nature into which they fit so completely. ... But how can I explain to you... what is passing me by, always captivating me anew, and yet cannot be described at all, because it has to be seen!

Kraepelin appeared to have developed a sense of respect for the people of Ceylon. He wrote in the same letter:

...it is just a new world, a completely new people, strange, but yet deeply related to us, a people of soft, contemplative beauty, who has lost its energy and resilience under the spell of southern nature. 
On 26 January, the brothers visited Hakgala Botanical Garden. Emil described the gardens as "wonderful and beautiful" despite having to carry his umbrella throughout the visit due to the incessant rain. They left Nuwara Eliya on 27 January to return to Colombo. That evening, after arriving in Colombo, the brothers relaxed on a beach, thinking about the trip to South India in the coming days. This evening on the beach was remembered with nostalgia by Emil in a letter he wrote to Karl in 1905, a year after the experience (20).

Two days later they left Colombo Harbor for Tuticorin, South India, on the steamer 'Norunga'. Emile and Karl Kraepelin spent four days in India.

\section{Arriving back in Ceylon and the journey to Galle}

The brothers arrived back in Colombo Harbour on the morning of 2 February 1904 . Due to the outbreak of plague in India, they could not disembark until they were medically cleared by the Ceylon harbor medical officer. Despite the delay, they started their journey to Galle on the same day. They travelled along the west coast of Ceylon, spending several hours in Kalutara before reaching their destination at $9 \mathrm{pm}$. Emil mentioned that one reason they decided to visit Galle was the fact that the city had been the base of the great German naturalist Ernst Haeckel (1834-1919). Haeckel spent two years in Ceylon (1881 and 1882) and wrote a book about the flora and fauna of the island (26). The time spent in Galle appeared to have created a very favourable impression on Emil Kraepelin. He made special mention of the coral banks in Galle in his memoir (11). The brothers left Galle on the evening of 4 February to head back to Colombo.

\section{Leaving Ceylon}

Emil and Karl Kraepelin spent three days in Colombo before boarding the ship 'Roon' on 7 February 1904 to head to Singapore on the next leg of their journey to Java. Apart from Java, Emil Kraepelin spent the largest part of his trip in Ceylon - close to four weeks.

\section{Visiting Ceylon on the way back home}

On the return journey from Buitenzorg East Java, the brothers arrived in Colombo Harbour on 10 April 1904. Their ship, the 'Preussen', was leaving Colombo for Aden around midnight. While they waited, the brothers and other distinguished travellers on the vessel were hosted by the German Consul for dinner at his official residence in Mount Lavinia. After dinner, they left Ceylon for the final time around midnight on 10 April 1904.

\section{Kraepelin and Buddhism}

Emil Kraepelin's memoir suggests he had the highest regard for Buddhism. He wrote that the teachings of
Buddha appeared to him as the "greatest religiousphilosophical achievement of the human mind" (11). It is not clear if this was a result of his journey to Ceylon or if this appreciation existed prior to that. Other than his correspondence in preparation for the trip to Java, there is very little direct evidence of Kraepelin's interest in Buddhism before 1903. However, there is certainly indirect evidence that Kraepelin had some awareness of Buddhism, prior to his trip. Nevertheless, it would be fair to assume that his experiences in Ceylon sparked Kraepelin's deeper interest in Buddhism (EJ. Engstrom, personal communication, April 6, 2020).

During his travels in Ceylon, Kraepelin was inspired to write a poem 'Buddha' by his visit to Shri Maha Bodhiya. This was one of the several poems Kraepelin wrote during his trip to Java.

\section{Buddha (9)}

\author{
In high trees' solemn silence \\ Buddhas enigmatic image thrones, \\ seeing into far-off worlds. \\ In devotion Asia's pilgrims deeply bow, \\ adorned with festive colours. \\ Their earnest rows lead to the bodhi trees \\ where once the Buddha \\ from this world removed, \\ listened to scared voices \\ in the boughs, \\ enthralled in the enlightenment's bliss. \\ The tree is greening still, \\ faithfully through millennia \\ guarded by the master's disciples. \\ His work still towers high \\ above superstitions murky flood, \\ defying hostile forces. \\ And in the tree the voices old \\ they whisper as before: \\ "Be wise and be good!"
}

The leaves Emil Kraepelin collected from the Bodhi tree were sent to two of his colleagues in Germany: Paul Julius Möbius (a neurologist and prolific writer on many topics including psychiatry; he was called one of the fathers of psychotherapy by Sigmund Freud (27)); and Ernst Kuhn (a philologist and Indologist who had studied the languages of India and Ceylon. He had pointed out relevant articles on the history and culture of India and Sri Lanka to Emil Kraepelin before his trip, which Kraepelin found to be very useful) (Figure 2). Kraepelin gave the photo that he took of the Burmese monks and the sonnet that was inspired by what he saw to Hermann Oldenberg (a German Indologist and Buddhist scholar, who translated the Dipavamsa and the Thervada Vinaya texts from Pali). 
Emil's correspondence indicates that he was interested in another well-planned scientific expedition to India and Ceylon, but the First World War (1914-1918) and the subsequent travel restrictions that were placed on German scientists prevented this. Kraepelin's interest in Buddhism appears to have become more fervent in the latter part of his life. He saw 'Die Leuchte Asiens' (The Light of Asia), a silent film about the life of the founder of Buddhism, Prince Siddhartha Gautama, in October 1925 in Munich. He had already made detailed plans, including buying ship tickets, for a long research trip to India and Ceylon in 1926 to examine mental illness in the "tribes that produced Buddhism". However, his death intervened (28).

\section{Kraepelin the family man}

The letters to his wife from Ceylon allow the reader to glimpse the loving and caring part of Emil Kraepelin. En route to Ceylon, he used a Malay dictionary to find the word for 'kiss' (in Malay, 'tjum' or 'cium') and playfully signed off all his letters with the phrase 'tjum, tjum, tjum!'. When in Colombo, he described to his wife how he went back to a trader in the city, avoiding the company of his brother, to buy her gifts. He gently rebuked his wife for not writing often enough to him and often asked after her wellbeing. The letters were also filled with little complaints about uncomfortable beds, insipid food, stale jam and bitter tea, as well love for his children.

\section{Kraepelin's impressions of Ceylonese people}

Emil Kraepelin's descriptions of the Ceylonese people revealed that some of the ideas he championed after his trip to Java were conceived or developed during this voyage. In the years following this trip, Kraepelin became more interested in the 'mental hygiene' of the German populace. He believed that urbanised society was shielding the German populace from adversities of the natural environment and was therefore at odds with the Darwinian law of natural selection. He worried that this would eventually lead the German race to degenerate $(6,7)$. He considered alcohol to be one of the several public toxins contributing to this degeneration.

Kraepelin's admiration of the Ceylonese people appear to be based on his belief that they were more in touch with nature, were hard working, peaceful in nature and were abstinent from alcohol. While juxtaposing Ceylonese against Germans, he still considered the Ceylonese to be primitive, as he believed them to be controlled primarily by emotion and basic drives, and not by will or intellect. However, his impressions of Ceylonese people could be viewed as almost enlightened, given the time in history he was making these observations.

\section{The impact of the trip}

Emil Kraepelin's time and experiences in Ceylon do not appear to have influenced his scientific thinking or research. However, he enjoyed his visit and would recall it, years later, in a letter to his brother with fond memories (20). Moreover, one of the plants he grew (around 1910) in the garden in his beloved lakeside country house in Pallanza (Italy) was a tea bush to remind him of his time in Ceylon (11).

In his memoir Kraepelin wrote: Imust say that the hopes I connected with this journey were not disappointed but were fulfilled beyond expectation. I had never felt so happy all my life as I did on this journey (11).

Emil Kraepelin's experience at Buitenzorg Asylum in Java led to a seminal publication on transcultural psychiatry, Vergleichende Psychiatrie (Comparative Psychiatry), in 1904, on the front page of the famous Centralblatt für Nervenheilkunde und Psychiatrie $(9,29)$.

Karl Kraepelin discovered several new species of animals and one such discovery was the terrestrial flatworm Bipalium depressum in 1905 (later corrected as Humbertium depressum), located in Peradeniya (30).

\section{Conclusion}

The letters Emil Kraepelin wrote to his wife of his experiences and impressions of the Ceylonese reveal aspects of his thinking and personality that need to be integrated into the understanding of this pioneer. Ceylon offered him the opportunity to pursue his interests in travel and Buddhism. His descriptions of the Ceylonese, while exposing the biases prevalent during his time, are still compassionate and respectful. If not for the First World War, it is likely that Kraepelin would have carried out more scientific work in Ceylon.

\section{Acknowledgments}

The author thanks Christoph Bendick for sharing Emil Kraepelin's letters and editing the manuscript, Sigi Gutjahr for helping with the translations and Christian Schmidt-Kraepelin for allowing the material to be published. The Historical Archives of the Max-Planck Institute for Psychiatry provided support in looking for some of the material that contributed to this article.

Angelo de Alwis, Victorian Institute of Forensic Mental Health, Melbourne, Australia

Corresponding author: Ade Alwis

http://orcid.org/0000-0002-1101-7129 


\section{References}

1. Engstrom EJ, Kendler KS. Emil Kraepelin: icon and reality. Am J Psychiatry 2015; 172: 1190-6.

2. Decker HS. The psychiatric works of Emil Kraepelin: a many-faceted story of modern medicine. J Hist Neurosci 2004; 13(3): 248-76.

3. Allik J, Tammiksaar E. Who was Emil Kraepelin and why do we remember him 160 years later? Trames 2016; 20: 317.

4. Becker K, Steinberg H, Kluge M. Emil Kraepelin's concepts of the phenomenology and physiology of sleep: The first systematic description of chronotypes. Sleep Med Rev 2016; 27: 9-19.

5. Müller U, Fletcher PC, Steinberg H. The origin of pharmacopsychology: Emil Kraepelin's experiments in Leipzig, Dorpat and Heidelberg (1882-1892). Psychopharmacology (Berl) 2006; 184(2): 131-8.

6. Shepherd M. Two faces of Emil Kraepelin. Br J Psychiatry 1995; 167: 174-83.

7. Engstrom EJ. "On the question of degeneration" by Emil Kraepelin (1908). Hist Psychiatry 2007; 18: 389-404.

8. Engstrom EJ, Weber MM, Burgmair W. Emil Wilhelm Magnus Georg Kraepelin (1856-1926). Am J Psychiatry 2006; 163: 1710 .

9. Jilek WG. Emil Kraepelin and comparative sociocultural psychiatry. Eur Arch Psychiatry Clin Neurosci 1995; 245: 231-8.

10. Bendick C. Emil Kraepelins Forschungsreise nach Java im Jahre 1904. [Doctoral dissertation]. Köln: University of Cologne; 1989.

11. Kraepelin E. Memoirs. Hippius H, Peters G, Ploog D, editors. Berlin: Springer Berlin Heidelberg; 1987.

12. Burgmair W, Engstrom EJ, Weber M, et al. editors. Emil Kraepelin. 8 vols. Munich: Belleville; 2000-2018.

13. Palm U, Möller H-J. Reception of Kraepelin's ideas 19001960. Psychiatry Clin Neurosci 2011; 65: 318-25.

14. Kohl F. The beginning of Emil Kraepelin's classification of psychoses. A historical-methodological reflection on the occasion of the 100th anniversary of his "Heidelberg Address" 27 November 1898 on "nosologic dichotomy" of endogenous psychoses. Psychiatr Prax 1999; 26: 105-11.

15. Noll R. The American reaction to dementia praecox, 1900 . Hist Psychiatry 2004; 15(1): 127-8.
16. Ion RM, Beer MD. The British reaction to dementia praecox 1893-1913. Part 1. Hist Psychiatry 2002; 13: 285-304.

17. Ion RM, Beer MD. The British reaction to dementia praecox 1893-1913. Part 2. Hist Psychiatry. 2002; 13: 419-31.

18. Kraepelin K. Lectures of Clinical Psychiatry. Johnston T, translator, 3rd English edition. New York: William Wood; 1913.

19. Burmair W, Engstrom EJ, Weber MM, Kraepelin E. Kraepelin in München: 1903-1914. Munchen: Belleville; 2006.

20. Hippius H, Möller H-J, Müller N, Neundörfer-Kohl G. The University Department of Psychiatry in Munich: From Kraepelin and his predecessors to molecular psychiatry. Berlin,: Springer; 2008.

21. Kraam A. The legacy of Kraepelin (essay review). Hist Psychiatry 2002; 13: 475-80.

22. Carpenter J, Mendis N, Samarasinghe D. The history of mental health care in Sri Lanka. Colombo: Marga Publications; 1988.

23. Skinner T. Fifty years in Ceylon: an autobiography. New Delhi: Asian Educational Services; 1995, pp. 219-20.

24. Gamburd MR. Breaking the ashes: The culture of illicit liquor in Sri Lanka. New York: Cornell University Press; 2008, pp.28-32.

25. Wright A. Twentieth Century Impressions of Ceylon: Its History, People, Commerce, Industries, and Resources. New Delhi: Asian Educational Services; 1999, pp.629, 636.

26. Haeckel E. A visit to Ceylon. Bell C, translator. New Delhi; Asian Educational Services; 1995.

27. Prideaux S. I am dynamite! A life of Nietzsche. New York: Tim Duggan Books; 2018.

28. Burgmair W, Engstrom EJ, Weber MM, Kraepelin E. Kraepelin in München: 1921-1926. Belleville; 2006, pp.68-69.

29. Kraepelin E. Comparative Psychiatry. In: Littlewood R, Dein S, editors. Cultural Psychiatry \& Medical Anthropology. London: The Athlone Press; 2000. p. 38-42.

30. Ritter-Zahony, R. von. Landplanarien aus Java und Ceylon, gesammelt von K. Kraepelin 1904. Mitth. Naturh. Mus. Hambur 1905; 22: 161-200. 